\title{
Sciendo
}

Administration, vol. 67, no. 3 (2019), pp. 41-63

doi: 10.2478/admin-2019-0020

\section{The Buchanan report and its aftermath: Implications for Irish regional planning}

\author{
Proinnsias Breathnach \\ Department of Geography, Maynooth University, Ireland
}

\begin{abstract}
The so-called Buchanan report, commissioned by the Irish government and published in May 1969, comprised a set of proposals for regional industrial development in Ireland over the period 1966-86. The main thrust of the report was the concentration of the great bulk of new industrial employment creation in Dublin and eight proposed 'growth centres'. The plan provided for the creation of powerful planning authorities to oversee development in the regions. The government rejected these proposals and opted instead to continue with the existing policy of widespread dispersal of new industry. While meeting with initial success, this policy proved unsustainable in the long term. The paper reviews the implications of the Buchanan report experience for the regional planning process in Ireland, arguing that failure to learn from this experience served to undermine the National Spatial Strategy, with a similar fate likely for the forthcoming National Planning Framework.
\end{abstract}

Keywords: Buchanan report, growth centres, regional planning authorities, regional industrial plans, National Spatial Strategy

\section{Introduction}

The year 2019 marks the fiftieth anniversary of the publication of the first comprehensive plan for regional development in Ireland 
commissioned by the Irish government. Formally entitled Regional Studies in Ireland, the plan was generally known as the 'Buchanan report' after the British planning consultancy firm, Colin Buchanan and Partners, which had primary responsibility for the production of the report (Colin Buchanan and Partners, 1968). This paper begins by providing the background to the commissioning of the Buchanan report. It then outlines the main elements of the report before providing an account of how the report fared in terms of subsequent implementation. The paper concludes with some reflections on how the report and its subsequent treatment impacted on regional development planning in Ireland in subsequent decades.

\section{Historical background}

When political independence was achieved in 1922, what was to become the Republic of Ireland was predominantly a rural country in which agriculture was by far the main source of employment. The election of the Fianna Fáil party to government in 1932 led to the introduction of a vigorous policy of protectionism, involving high tariff walls designed to encourage the establishment of indigenous industries to supply the domestic market. This led to significant growth in manufacturing employment, which by 1951 was fifty per cent higher than in 1926 and accounted for 14.2 per cent of total employment. In spatial terms, most of this employment growth occurred in the main urban centres, and especially in Dublin and the surrounding counties (Gillmor, 1985). By 1961 Dublin County alone accounted for almost one-half of total manufacturing employment, twice its share of the national population.

In 1958 the government abandoned protectionism and introduced the policy for attracting export-oriented foreign investment which has been the mainstay of Irish industrial development policy ever since. From the beginning, the Irish government pursued an informal policy of seeking to disperse incoming plants as much as possible around the country, with particular preference for rural districts. Undoubtedly, this policy was linked to the fact that the governing party, Fianna Fáil, had a strong electoral base in the rural regions of the west and northwest.

However, this approach was questioned in a number of reports by government agencies and advisory bodies in the early 1960s. In 1961 the government established the Committee on Industrial Organisation (CIO) to prepare Irish industry for the opening of the economy to 
international free trade, which was seen as essential to the policy of attracting export-oriented foreign investment and was a core element of the government's First Programme for Economic Expansion 1958-63. In a 1963 report on industrial grants policy, the CIO criticised the government's industrial policy as being economically unjustifiable, due to the deficiencies of isolated locations in terms of infrastructure, availability of business services, education and training facilities, and the operational difficulties which would arise from a labour force lacking skills and industrial tradition. Arguing that most firms would be more likely to prosper in locations where they could avail of 'the advantages which tend to be found in areas where there are concentrations of industry' (Committee on Industrial Organisation, 1963, p. 12), the CIO recommended the selection of a number of centres for major industrial development which would offer special inducements to attract new enterprises. Such an approach, it was envisaged, would, in the long run, attract more investment while requiring a lower level of subsidisation than the existing policy of dispersal. The CIO also proposed the idea that growth would 'radiate' from the proposed development centres to their hinterlands, so that all areas would benefit from the recommended approach, although it did not spell out how this process would operate.

The government responded to the CIO report by establishing a special committee - the Committee on Development Centres and Industrial Estates - to consider the issue further. Its report, submitted to the government in 1965, endorsed the CIO arguments that development centres would attract investment which would not otherwise locate in Ireland and would also generate spin-off growth in their surrounding hinterlands (Committee on Development Centres and Industrial Estates, 1965). The committee also suggested that development centres would have a stimulatory impact on indigenous industry arising from the facilities which would be available in the centres and the additional business which the centres would generate. Drawing on the success of the industrial estate set up in 1958 at Shannon Airport (where a customs-free industrial zone had been created), the committee further recommended the establishment of such estates in the selected development centres.

While the committee's report was subsequently endorsed by the government's economic policy advisory body, the National Industrial and Economic Council (1965), when the government finally issued a policy statement on the development centre issue in August 1965 (reproduced in National Economic and Social Council, 1975), it was 
largely hostile to the idea. While accepting that such centres 'could be an effective means of promoting the further expansion of economic activity' and that 'secondary centres will benefit from growth at the primary centres', the statement argued that 'the dispersal of economic activity throughout the country' yielded 'important social advantages'. The government, therefore, intended to continue pursuing this policy. In its one concession to the development centre argument, the government statement did commit to the establishment, on an experimental basis, of industrial estates at Galway and Waterford, the function of which was 'to attract thereto industries which might not be located in Ireland at all but for the facilities offered at these estates'.

\section{Preparation of the Buchanan report}

The 1963 Local Government (Planning and Development) Act introduced formal land-use planning by local authorities in Ireland. While the new planning system was primarily the responsibility of urban and county councils, provision was also made for the preparation of strategic regional plans which would provide the frameworks to guide the preparation of subregional local plans (Bartley, 2001). For this purpose the country was divided into nine planning regions in 1964. The government initially engaged international planning consultants to prepare regional plans for the Dublin and Mid-West (focused on Limerick city) regions and then, in 1966, requested the United Nations Development Programme (UNDP) to source consultants who would undertake regional studies of the seven remaining regions which would provide a basis for formulating physical development plans for these regions. In October of that year, the British consultancy firm Colin Buchanan and Partners was duly commissioned to carry out this undertaking.

The specific remit, as set out by the UNDP, involved an assessment of the growth potential of the regions, identification of possible development centres, establishment of the infrastructural investments required to facilitate growth of the regions, and formulation of development policy proposals to be presented to the government, including the measures required for implementation of these proposals. It was subsequently agreed between the consultants and the UNDP that the Dublin and Mid-West regions would be incorporated into the exercise in order to facilitate the preparation of a comprehensive, coordinated, national plan for regional development. 
Originally a road and traffic engineer by training, Colin Buchanan joined the UK Ministry for Town and Country Planning after the Second World War. He achieved some fame with the publication in 1963 of a celebrated report entitled Traffic in Towns, prepared for the UK Ministry of Transport. An abridged version was published by Penguin in 1964 (Buchanan, 1964). This report had a major influence on urban transport planning in the UK and elsewhere. In 1964 Buchanan both entered academia at Imperial College, London, and also set up his planning consultancy company, Colin Buchanan and Partners (Buchanan, 2001).

In order to supplement the firm's specialisms in urban planning and transport, the services of a second consultancy firm, Economic Consultants Ltd of London, were engaged to conduct the demographic, economic and industrial elements of the Irish study. The principal of this firm, William Luttrell, had conducted pioneering research in the 1950s on the location of industrial branch plants whose emergence was exerting a significant impact on the geography of British manufacturing at the time (Luttrell, 1962). This expertise was of obvious relevance, in view of the growing importance of foreign branch plants in the Irish economy in the 1960s. In order to provide specific expertise on Irish circumstances, Buchanan availed of the services of a number of economists, geographers and planners from An Foras Forbartha (The National Institute for Physical Planning and Construction Research), which had been established in 1964 to act as an advisory and research resource for the nascent Irish physical planning system.

\section{The Buchanan report: Key elements}

What was to become known as the Buchanan report was submitted to the Irish government in September 1968. The actual title of the report - Regional Studies in Ireland - is rather misleading, as it gives the impression of a report comprising a compendium of individual regional profiles and plans, which indeed is what appears to have been envisaged by the government when it first approached the UNDP, as reflected in the latter's request to Buchanan to 'undertake regional studies for seven of the nine planning regions' (Colin Buchanan and Partners, 1968, p. i). In fact, the report assumes a national standpoint throughout, while at the same time presenting a lengthy series of distribution maps of various indicators from which regional trends are identified and a picture of the regional configuration of the economy is built up. 
The report next sets out forecasts of population and employment growth up to 1986 (nationally) based on observed current trends, and considers the possibilities of varying these forecasts via regional policy interventions. The likely impacts, at both national and regional level, of different regional development approaches are then assessed. These include concentrating new industrial development as much as possible in Dublin; concentrating development in Cork City and Limerick-Shannon (Shannon being included with Limerick city due to its proximity to the latter and the successful performance of the industrial estate located there); distributing industrial growth among the main regional urban centres (in proportion to each region's share of the national population); and dispersing development as much as possible throughout the country's twenty-six counties.

In assessing the likely impact of each of these development options on industrial and population growth (industrial growth seen as being the main driver of general economic growth and thus population growth), the report examines the merits and demerits of both dispersal and spatial concentration policies. While it acknowledges that some firms, mainly those of small size and limited skill and support-service requirements, may be quite happy to locate in smaller towns, the report argues that the kinds of industrial plants which Ireland should be seeking to attract in terms of long-term development - i.e. of large size and in advanced-technology sectors - are likely to require locations in larger urban centres. The report concludes that, on balance, concentrated development is likely to lead to superior returns in terms of industrial growth. Some foreign firms would be attracted to Ireland which would otherwise not be; firms, once established, would be more likely to expand in larger centres; more indigenous Irish firms would be generated in larger centres (due to the availability of skilled labour and specialist services and possible demands generated by foreign firms); and costs would be lower, leading to greater export competitiveness. Accordingly, a concentration policy was considered to be essential to the acceleration of the development of the Irish economy, which would be required in order to meet the government's published aim of reducing emigration to 5,000 per annum by 1986 .

The report considered that a policy of concentrating growth in Dublin would be most effective in terms of maximising national industrial and population growth. However, it was deemed that the negative consequences of such a policy, including spatial imbalance in the national economy, increased population decline in rural regions, poorer service provision in regional centres, and problems of amenity 
and congestion in the Dublin region itself, rendered this option politically unacceptable. Buchanan's second-best option was to concentrate resources in the creation of two major industrial centres at Cork and Limerick-Shannon, capable of competing effectively with Dublin for mobile investment. The decision to opt for two centres rather than one was based on the expectation that trying to create a single centre of larger size within the envisaged policy time-frame would present 'insuperable practical problems on the ground' (Colin Buchanan and Partners, 1968, p. 110).

Buchanan sought to create in Cork and Limerick-Shannon 'industrial complexes' of interlinked activities, built around a set of core firms whose mass would in turn generate a web of spin-off specialist services and facilities and ancillary industries. The interaction between these components would, it was hoped, create a dynamic which would generate a process of self-sustaining growth, thereby obviating the need for ongoing public support. Evidence elsewhere suggested that industrial complexes with these characteristics tended to be located in cities of a different scale of magnitude to Cork and Limerick-Shannon. However, Buchanan felt that, where carefully and deliberately planned, successful industrial complexes could be created in much smaller industrial centres. Buchanan contrasted the envisaged type of industrial structure with the existing industrial estate in Shannon, which, despite its impressive growth, comprised a set of firms with little internal interaction and little demand for local services and which therefore offered no prospects of self-sustaining growth. 'The lesson is that to build a base for self-generating industrial growth requires a much larger-scale and more comprehensive type of planning' (p. 103) than was represented by the Shannon estate.

While the report makes very few references to international literature, its discussion of the merits of spatial concentration of industry and its use of terms such as 'industrial complex', 'ancillary industries' (which supply inputs to core firms) and 'self-sustaining growth' indicates familiarity with the literature on growth centres which had begun to emerge in the mid 1960s (Boudeville, 1966; Darwent, 1969; Hansen, 1967). This literature generally argued that a policy of concentrating growth in key regional centres was likely to prove more effective as a driver of growth in peripheral rural and declining industrial regions than the policy of dispersed branch-plant industrialisation which had emerged in the 1950s and 1960s as a leading regional development device in many advanced economies. 
While the development of Cork and Limerick-Shannon as major industrial centres remained the main focus of the Buchanan development proposals, in the interests of greater regional balance, it was decided to add a second tier of six growth centres which would also receive favoured treatment, even though this would mean a slightly lower level of overall employment and population growth. While the former were designated as 'national' growth centres in the final plan, the latter were termed 'regional' growth centres (Figure 1). Three of these - Waterford, Dundalk and Drogheda - were already established industrial centres, which were thought to offer prospects of significant further industrial growth. For the other three (Galway, Athlone and Sligo), the development of their service bases (as regional centres) was considered as important for their future growth as the expansion of their industrial bases (the development of its role as a regional service centre was also to be an important element of Waterford's expansion). The strategy also provided for four 'local' growth centres (Castlebar, Cavan, Letterkenny, Tralee) in peripheral, rural regions, which would be mainly promoted as service centres for their surrounding hinterlands. Under the plan, Dublin was to be allowed to 'grow naturally': while no incentives would be provided for industry to locate in the capital, neither would there be any measures to restrict its growth. This approach, it was thought, offered the optimal combination of national employment and prosperity growth and equitable distribution of growth between regions.

While the report provides estimates of national population and manufacturing employment growth up to 1986 with a continuation of existing industrial location policies favouring dispersal, and also provides an estimate of population growth under its growth centre proposals, strangely it does not provide an estimate of overall manufacturing employment growth under these proposals. However, using the ratio between projected industrial and population growth under existing policies, the additional manufacturing employment which would have been created by 1986 under the Buchanan proposals amounts to $160,000-20,000$ more than the projected growth under existing policies.

The report also provides projections of manufacturing employment and population growth in Dublin, Cork and Limerick-Shannon but only provides population growth projections for the regional growth centres. Using the ratio between manufacturing employment and population growth for the three larger centres (roughly 25,000 population growth per 5,000 growth in manufacturing jobs), the 
Figure 1: Buchanan report growth centre proposals

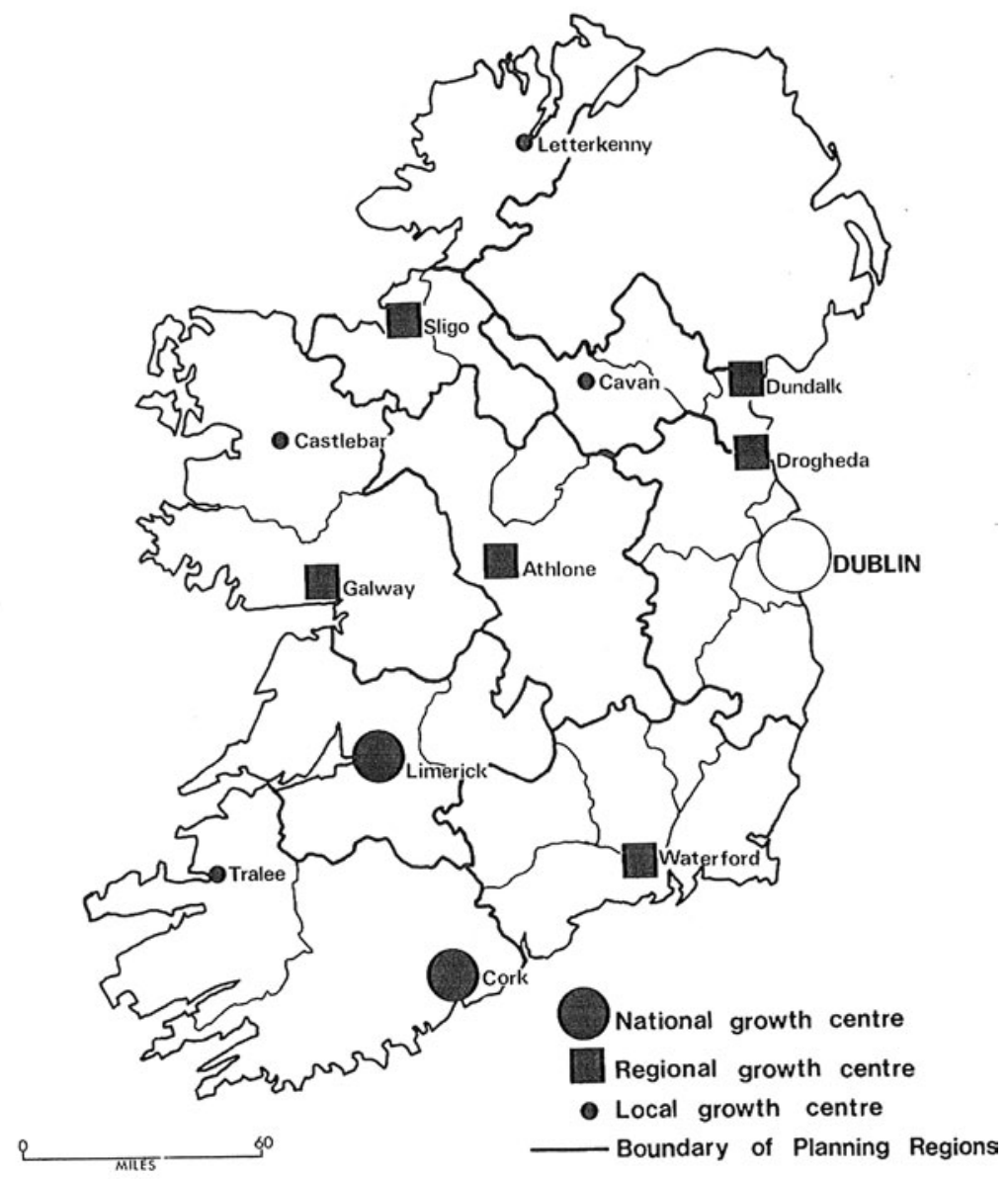

overall distribution of manufacturing employment growth under the Buchanan proposals has been calculated as shown in Table 1 (in which the data for individual urban centres refer to the number of people in manufacturing employment living in these centres, rather than the actual number of manufacturing jobs in the centres, data for which were not available). This shows the projected growth in manufacturing employment nationally, and for Dublin, Cork, Limerick-Shannon, the proposed regional growth centres (combined) and the rest of the country, under the Buchanan proposals. These projections are for 1961-86 as the employment data from the 1966 population census 
were not yet available at the time the report was being compiled. For comparison purposes, the corresponding distribution of manufacturing employment in the 1966 census is also shown (the 1961 population census does not provide a breakdown of employment by individual towns).

\section{Table 1: Projected distribution of additional industrial employment under Buchanan proposals}

\begin{tabular}{lcrcr}
\hline & $\begin{array}{c}\text { Manufacturing } \\
\text { employment } \\
1966\end{array}$ & $\%$ Total & $\begin{array}{c}\text { Additional } \\
\text { manufacturing } \\
\text { employment } \\
\text { 1961-86 }\end{array}$ & $\%$ Total \\
\hline Total & 198,297 & 100.0 & 160,000 & 100.0 \\
Dublin & 88,154 & 44.5 & 65,000 & 40.6 \\
Cork & 14,427 & 7.3 & 25,000 & 15.6 \\
Limerick-Shannon & 6,158 & 3.1 & 20,000 & 12.5 \\
Regional centres & 14,348 & 7.2 & 22,000 & 13.8 \\
Rest of country & 75,210 & 37.9 & 28,000 & 17.5 \\
\hline
\end{tabular}

The table shows that Dublin was expected to attract a slightly lower proportion of additional manufacturing employment than its existing share, reflecting the capital region's attraction for manufacturing firms, even in the absence of locational incentives. The key feature of the table is the difference in expected performances between Cork and Limerick-Shannon. Despite its much smaller initial manufacturing base, Limerick-Shannon was projected to experience much stronger employment growth (225 per cent compared with 73 per cent for Cork), even though similar developmental structures were proposed for both centres (see below). Indeed, the projected growth of Cork was only slightly superior to that of the proposed regional growth centres (which, combined, had an almost identical starting base to Cork's), even though, in contrast to Cork, no specific organisational structures for promoting development were proposed for the latter. This substantial difference in projected growth performance between Cork and Limerick-Shannon is not alluded to in the report. However, in its discussion of Limerick-Shannon's developmental prospects, the report attributes specific importance to the growth of the Shannon Industrial Estate, and the fact that the estate's promotional organisation had recently had its remit extended to the entire MidWest region, including Limerick city. The final point of note in Table 1 is that the rest of the country, outside Dublin and the proposed 
growth centres, was projected to account for less than 20 per cent of additional manufacturing employment - less than half of its existing share of the national total.

These proposals for the distribution of additional manufacturing jobs are reflected in the report's projected distribution of the national population in 1986. Table 2 shows the distribution, in 1966, of the national population between Dublin, the proposed growth centres, and the rest of the country, and how this distribution was projected to change by 1986 with a continuation of existing policies and under the Buchanan proposals.

Table 2: Population change scenarios, 1966-86

\begin{tabular}{|c|c|c|c|c|c|}
\hline & $\begin{array}{c}1966 \text { Pop. } \\
\text { (000) } \\
\text { actual }\end{array}$ & $\begin{array}{c}1986 \text { Pop. } \\
\text { (000) } \\
\text { current } \\
\text { policies }\end{array}$ & $\begin{array}{c}\% \\
\text { Change }\end{array}$ & $\begin{array}{c}1986 \text { Pop. } \\
\text { (000) } \\
\text { Buchanan } \\
\text { proposals }\end{array}$ & $\begin{array}{c}\% \\
\text { Change }\end{array}$ \\
\hline Total & 2,884 & 3,355 & 16 & 3,498 & 21 \\
\hline Dublin & 795 & 1,075 & 35 & 1,125 & 42 \\
\hline Cork & 125 & 170 & 36 & 250 & 100 \\
\hline Limerick-Shannon & 60 & 135 & 125 & 175 & 192 \\
\hline Waterford & 30 & 55 & 83 & 55 & 83 \\
\hline Galway & 26 & 45 & 73 & 47 & 81 \\
\hline Dundalk & 22 & 45 & 105 & 44 & 100 \\
\hline Drogheda & 18 & 35 & 94 & 35 & 94 \\
\hline Sligo & 13 & 20 & 54 & 30 & 131 \\
\hline Athlone & 11 & 15 & 36 & 18 & 64 \\
\hline Regional centres & 120 & 215 & 79 & 229 & 91 \\
\hline Rest of Ireland & 1,784 & 1,760 & -1 & 1,719 & -4 \\
\hline
\end{tabular}

The total population was projected to increase by 16 per cent with a continuation of existing policies and by 21 per cent under the Buchanan development proposals, the higher rate of growth being attributable to the increased employment and reduced emigration which were expected to arise from the implementation of these proposals. Dublin's population was projected to grow by twice the national rate under both scenarios, its higher rate under the Buchanan proposals being attributed to Dublin's inherent ability to capture a substantial share of the additional employment which would be generated by the proposals. While Cork's population was projected to double under the proposals, that of Limerick-Shannon was projected 
to treble, in line with the much more rapid rate of industrial growth projected for the latter, as discussed above. Indeed, even in the absence of the Buchanan proposals, Limerick-Shannon was expected to experience spectacular growth, presumably as a consequence of the growth of the Shannon Industrial Estate and the extension of the Shannon promotional organisation's extension to Limerick.

As expected, in aggregate the proposed regional growth centres were projected to grow at a similar rate to Cork, given the similarity between them in initial population and manufacturing employment base and expected industrial growth over the period. However, there were significant internal differences within the group of regional centres, with Dundalk, Drogheda and especially Sligo expected to enjoy substantially higher growth rates than Waterford and Galway. No reasons were given for these differences, although Dundalk and Drogheda may have been expected to derive spin-off benefits from their proximity to Dublin. Athlone's relatively modest growth rate, from a small initial base, is also notable. However, what is particularly notable from the table is the fact that the projected 1986 populations for the four largest regional centres (and those with the strongest initial industrial bases) are virtually identical under both scenarios. In other words, the Buchanan proposals were, in essence, expected to have no effect on the growth of these centres over the plan period. This would suggest that the inclusion of the six regional centres in the proposals was largely a token gesture.

\section{Implementation arrangements}

The report's major proposal as regards plan implementation was the creation of a set of powerful statutory planning authorities to oversee the execution of the plan at regional level. The country would be divided into eight 'planning areas' (PAs), generally in line territorially with the nine planning regions established in 1964, with the exception that the Donegal planning region would be incorporated into the North-West PA (centred on Sligo) along with the northern half of County Mayo and parts of north Roscommon and west Cavan. Each PA would have as its focus one of the proposed growth centres, apart from Drogheda, whose neighbour, Dundalk, would be the focal centre of the North-East PA. Dublin would be the centre of its own surrounding PA (incorporating counties Meath, Kildare and Wicklow). This structure complies with a general proposal in the report that all planning authorities should include both central towns 
and their surrounding rural hinterlands in the interests of effective planning.

The function of the proposed planning authorities would be to prepare and implement an overall development plan for each PA; they would also have full statutory responsibility for all significant planning decisions within the PAs. The envisaged remit for the authorities would overlap considerably with the physical planning functions of the local authorities, which, because of the statutory status of the regional plans, would be required to work to the latter plans. Indeed, the report raises the possibility that the new regional structures might require 'radical reorganisation' of the local government system but does not go further into this.

Because of the nature and scale of development envisaged for Cork and Limerick-Shannon, the report proposed the creation of special agencies to oversee development in these centres. These would resemble the development corporations which were set up in the UK to implement the post-war New Towns programme and which were subsequently used to oversee major expansions of much larger cities such as Northampton and Peterborough. They would have very extensive powers, including responsibility for land-use planning, transport and communications infrastructure, and all other major construction projects (including housing, industrial estates, and education and other public service facilities).

The work of these development corporations would be closely coordinated with separate industrial development agencies, whose specific remit would be the comprehensive, 'careful and discriminating planning' of all parts of the industrial complexes to be built up in both centres. This would involve the cultivation of a core group of exporting firms in a particular sector or related sectors of sufficient mass to stimulate the establishment of a range of specialist support services and ancillary industries, thereby creating a level of internal interaction capable of generating the kind of self-sustaining growth process discussed earlier in the paper. The report saw the Shannon Free Airport Development Company (SFADCo) as providing the nucleus for the kind of industrial development agency required for LimerickShannon, with a similar agency to be established in Cork.

The report also proposed that industrial grants would be made available to firms locating in the two centres at the same level as those available in the western designated areas, where grants could be up to 15 percentage points higher than in the rest of the country. As regards the six regional growth centres, not only did the report not propose 
any special administrative structures to oversee their development, the only special incentive which was suggested to attract industry thereto was scope to provide additional grant aid for firms deemed particularly suitable, at the discretion of the Industrial Development Authority (IDA) (the government's industrial development agency), for location in one of the six centres. This adds further to the impression, suggested earlier, that the report's engagement with this element of its plan was little more than tokenistic.

While the report states that the articulation and overall direction of its proposed plan is the responsibility of central government, it makes no proposals regarding administrative arrangements for the performance of these functions at this level, apart from pointing to the need for coordination within the public sector in pursuit of the plan's objectives. In order to facilitate this at regional level, the report recommends that the regional structures of government departments and state agencies should be adjusted to coincide with the PAs proposed for the preparation and implementation of regional plans.

\section{Government response}

The Buchanan report was submitted to the government in September 1968. The fact that it was not published until May 1969 was in itself an indication of disquiet with its proposals within government circles. These reservations became apparent in the policy statement which accompanied the report's publication (reproduced in National Economic and Social Council, 1975). In this statement the government accepted 'in principle, that growth centres can be a valuable element in a regional programme' but felt that 'A growth centre programme on the lines recommended by the consultants would have far-reaching implications ... for development prospects in other areas'. The government had decided, therefore, that the consultant's growthcentre recommendations 'should be further considered in the context of proposals for regional development generally'. This, in effect, signalled the death knell for the report's proposals.

The policy statement did announce the establishment of regional development organisations for the planning regions, supposedly to coordinate regional development programmes, but these turned out to be toothless entities in contrast with the powerful regional planning authorities envisaged by Buchanan. The statement further committed the IDA to continue to support 'the preference of some industrialists for locations outside the main population centres'. To facilitate this, 
the IDA was to commence construction of ready-built advance factories and the acquisition of serviced industrial sites at various locations throughout the country.

Exactly three years passed before the government issued a further policy statement on regional planning, in May 1972 (reproduced in National Economic and Social Council, 1975). This statement set out a regional policy which 'should not merely seek the attainment of required national growth rates but should also provide for the maximum spread of development, through all regions, giving an increased and wider range of economic and social opportunities and so minimising population dislocation through internal migration' (attainment of the Buchanan proposals would have involved a substantial level of internal migration). The statement did make a nod to Buchanan by including a stated objective of restricting the growth of Dublin to the level required to accommodate natural population increase while also providing for the expansion of the eight growth centres identified by Buchanan. However, the statement also provided for 'development of county or other large towns of strategic importance in each region, including relatively large expansion of towns in areas remote from existing towns', while 'smaller urban areas' would also share in the expansion process. All told, the combined population of towns apart from Dublin and the eight Buchanan growth centres was projected to grow by 65.7 per cent over the period 1966-91.

The statement included population growth projections for the state as a whole and for Dublin and the eight Buchanan growth centres for the 25-year period 1966-91. These revealed serious inconsistencies with the regional policy as presented in the statement. Table 3 summarises these projections by showing the population projections for Dublin, the combined Buchanan growth centres and the rest of the country, and compares these with the corresponding Buchanan projections. The table indicates a higher growth rate for the Buchanan growth centres than that envisaged by Buchanan (even allowing for the extra five-year period involved), so that their share of total employment in 1991 (20.2 per cent) was projected to be significantly greater than that projected by Buchanan (18.7 per cent). With Dublin's share of the population much the same for the two projections, therefore, the government's projections actually envisaged a greater concentration of population in Dublin and the Buchanan growth centres (51.6 per cent) than that proposed by Buchanan (50.9 per cent), which is clearly at odds with the 
government's rejection of the Buchanan proposals in its 1969 policy statement and its commitment to a wider spread of development in its 1972 statement.

Table 3: Population distribution projections

\begin{tabular}{|c|c|c|c|c|c|c|c|c|}
\hline & \multicolumn{2}{|c|}{$\begin{array}{c}1966 \\
\text { (Actual) }\end{array}$} & \multicolumn{3}{|c|}{$\begin{array}{c}1986 \\
\text { (Buchanan) }\end{array}$} & \multicolumn{2}{|c|}{$\begin{array}{c}1991 \\
\text { (Government) }\end{array}$} & \multirow[b]{2}{*}{$\begin{array}{c}\% \\
\text { Change }\end{array}$} \\
\hline & $(000)$ & $\%$ & $(000)$ & $\%$ & $\begin{array}{c}\% \\
\text { Change }\end{array}$ & $\begin{array}{l}(000) \\
\end{array}$ & $\%$ & \\
\hline Total & 2,884 & 100.0 & 3,498 & 100.0 & 21.3 & 3,700 & 100.0 & 28.3 \\
\hline Dublin & 795 & 27.6 & 1,125 & 32.2 & 41.5 & 1,162 & 31.4 & 46.2 \\
\hline $\begin{array}{l}\text { Growth } \\
\text { centres }\end{array}$ & 305 & 10.6 & 654 & 18.7 & 114.4 & 747 & 20.2 & 144.9 \\
\hline $\begin{array}{l}\text { Rest of } \\
\text { Ireland }\end{array}$ & 1,784 & 61.9 & 1,719 & 49.1 & -3.6 & 1,791 & 48.4 & 0.4 \\
\hline
\end{tabular}

Table 3 also shows that the government envisaged virtually no change in the population outside of Dublin and the growth centres between 1966 and 1986. Thus, the 65.7 per cent growth in the urban population outside these centres proposed in the government statement, combined with the 144.9 per cent growth envisaged for the growth centres, necessarily implied a major reduction in the rural population and a high resultant level of rural/urban migration. This clearly runs counter to the commitment to 'minimising population dislocation through internal migration' contained in that statement.

\section{The IDA regional industrial plans}

A further anomaly arose in relation to the regional industrial plans which were being prepared by the IDA in 1972, and a preliminary statement on which was published simultaneously with the government's statement on regional policy. These plans were in preparation on foot of the IDA having been assigned statutory responsibility for promoting regional industrial development in 1969. In its policy statement, the government endorsed the approach being adopted by the IDA as being consistent with its own regional strategy statement. Yet when the final regional industrial plans were published only one month later, they proposed to locate just 52 per cent of the new jobs to be created over the plan period (up to 1977) to Dublin and 
the eight Buchanan centres. This contrasts with the $80+$ per cent of additional manufacturing employment which Buchanan proposed to locate in these centres and the similar level of concentration implied by the government's own population projections. Clearly, the IDA plans implied a much lower level of concentration than would be required to achieve these projections.

In fact, the IDA's regional plans represented an almost complete abandonment of the idea of spatial concentration of new industrial employment. The IDA rejected the idea that incoming firms were resistant to locating outside urban centres, pointing out that during the 1960s new industrial plants had been established in 271 different locations, with one half of these plants being located in towns of less than 3,000 population. Despite the dispersal policy, there had been a marked acceleration in new inward investment in the late 1960s (Industrial Development Authority, 1972).

The IDA regional plans therefore sought to put the dispersal policy on a systematic footing by dividing the country into forty-eight groups of neighbouring towns, for each of which a job creation target was set over the plan period. The main device for achieving these targets would be the targeted construction of advance factories at various locations. During the period over which the regional plans operated (1973-82), the IDA (and Shannon Development - the successor to SFADCo - in the Mid-West region) constructed 432 advance factories in 156 different locations (Breathnach, 1991). The allocation of advance factory floor space was strongly biased in favour of smaller centres. It is estimated that advance factories accounted for over 40 per cent of total employment created by the IDA over the period in question.

The surge of inward investment which followed Ireland's entry to the EEC in 1973 played a key role in helping the IDA to achieve its regional targets. By 1981, over half of all manufacturing employment in the largely rural West, Mid-West and North-West regions was accounted for by foreign firms (Gillmor, 1985). At the same time, the free trade conditions which followed from EEC entry, allied to the major international recession which occurred in the mid 1970s, had a devastating effect on much of the inefficient older industry which was primarily located in Dublin and the other major cities. The combination of job losses in the urban regions and strong growth in the more rural regions led to a remarkable regional redistribution of manufacturing employment in this period (Breathnach, 1982). 
The ability of the IDA to get incoming firms to locate in small-town and rural locations was largely predicated on the fact that the jobs being provided by these firms were largely unskilled, in such areas as electronic and electrical assembly and pharmaceutical packaging (Breathnach, 1993). This, however, proved a major liability as Ireland became a more high-cost environment with the increasing inflow of investment in high-technology manufacturing and services seeking more highly skilled workers (Breathnach, 1998), allied to the emergence of new low-cost competitors in routine unskilled manufacturing (especially China), in the 1990s. Already, the severe recessionary conditions of the early 1980 s had led to the contraction and closure of much of the existing base of foreign firms, and this process accelerated in the 1990s so that, today, very few of the industrial plants attracted to Ireland in the 1970s are still operational.

\section{Regional planning implications}

The case of the Buchanan report and its aftermath contains many lessons for how regional development policy in Ireland could be better formulated and implemented. Unfortunately, the evidence indicates that those responsible for regional policy have been unable, and probably unwilling, to take these lessons on board in subsequent exercises in regional development planning. This is apparent in the similar fate which befell the National Spatial Strategy, while the initial indications are that the failure to absorb these lessons will also imperil the forthcoming National Planning Framework (NPF).

The principal issues to arise from the government's response to the Buchanan report were the Irish political system's prioritisation of short-term electoral considerations over long-term planning, and in particular that system's localistic preoccupations, which induced the rejection of the spatial selectivity required by the Buchanan development proposals (Breathnach, 2010). In this respect, while it proved unsustainable in the long term, the initial success of the IDA's extreme dispersal policy in the 1970s created an expectation among Irish politicians that industrial plants could be delivered almost at will to particular localities, and this unfounded expectation has proven difficult to shake off. New inward investment to Ireland since the 1990s, dominated by high-tech manufacturing and services activities, has shown a strong preference for larger urban centres (and particularly Dublin). International thinking on regional development strongly favours the fostering of strong urban centres, capable of 
attracting such investment, in non-metropolitan regions - this was a key element of the European Spatial Development Perspective, the model for promoting balanced regional development adopted by the EU member states (including Ireland) in 1999 (Breathnach, 2014). The basic argument here is that the only way peripheral regions will attract significant amounts of inward investment is through the concentration of development in their regional centres. This was the premise underpinning the gateway centres that lay at the core of the National Spatial Strategy, which, like the Buchanan report, fell by the wayside in large part due to political resistance to its implementation (Breathnach, 2014). There is no reason to believe that similar problems will not beset the NPF, which - with its emphasis on the development of the Cork, Limerick, Galway and Waterford 'city regions' - appears to be even more spatially selective than the Buchanan report and the National Spatial Strategy.

A second key issue which served to undermine the prospects of the National Spatial Strategy's gateway proposals being effectively implemented was the strategy's failure to address the governance requirements of these proposals (Breathnach, 2014). These were anticipated by the Buchanan report, with its proposals for the creation of eight regions, each focused on a regional growth centre; the establishment in each of these regions of a powerful planning authority to formulate and implement a development plan for that region; and the creation of special development agencies to oversee development in the two major growth centres at Cork and LimerickShannon. Buchanan also adverted to the probable need for radical reorganisation of subregional local government which these proposals would entail.

Many of these issues have reappeared subsequently in the international literature on regional development, and in particular in a strand of this literature which has become known as the 'new regionalism' (Keating, 1998). This refers to a widespread process over the last thirty years, especially in Western Europe, of devolution to subnational regions of responsibility for their own affairs (Loughlin, 2001). In the regional development sphere, this trend has been driven, in large part, by a realisation that traditional centralised and top-down policies have been of limited effectiveness and lacking in flexibility. By contrast, endogenous bottom-up approaches are seen as offering the prospect of more comprehensive and better coordinated development programmes tailored to local needs and resources, and more capable of promoting local linkages and innovation (Parkinson et al., 1994; 
Pike et al., 2006). Key features of the new regionalism are its focus on the city-region as its basic organisational construct and the creation of new governance structures operating at the regional level, embracing a wide range of regional actors, and entailing a high level of regional control over key functions relevant to the development process (Breathnach, 2014; Brenner, 2004).

While the gateway cities which were a central element of the National Spatial Strategy did point to the need to build the development of the regions around their core cities, the strategy contained no proposals for creating the kind of regional governance structures seen elsewhere as being key to effective regional development. Indeed, the lack of provision for appropriate governance structures was identified as a key weakness by several assessments of the National Spatial Strategy (Breathnach, 2014; Forfás, 2006; National Competitiveness Council, 2009; National Economic and Social Council, 2008).

The extraordinarily brief review of the National Spatial Strategy prepared by a government-appointed Expert Group as part of the preparation of the NPF (Expert Group, 2014) makes no reference to these governance issues (nor indeed to the lack of buy-in by both the political and administrative arms of government, which greatly undermined both the National Spatial Strategy and the Buchanan report). The NPF does make some minor proposals regarding governance structures, including the establishment of the Office of the National Planning Regulator, one of whose functions will be to oversee implementation of the NPF strategy, and the preparation of metropolitan area strategic plans for the four main regional cities (with echoes of the special development agencies for Cork and Limerick-Shannon in the Buchanan report). The NPF also espouses the idea of building regional development around the 'city region' construct, although the three unwieldy regions for which regional spatial and economic strategies are to be prepared bear no relationship to the city-regional structure of the Irish space economy. Furthermore, the regional assemblies tasked with producing these strategies have few functions and no powers to enforce compliance with the strategies on the part of actors within their territories (Breathnach, 2017). Nor does the NPF make any proposals for the devolution of functions and powers to the local government system, contrary to the strong arguments in this respect set out in the government's Action Programme for Effective Local Government (Department of the Environment, Community and Local Government, 2012). 


\section{Conclusion}

Fifty years ago the Buchanan report presented ambitious proposals for how the growing dominance of the Irish economy by Dublin could be, at least partly, counteracted and development spread, in a sustainable way, to the country's non-metropolitan regions. In this writer's view, the key elements of these proposals - the cultivation in the main regional centres of self-sustaining complexes of interdependent enterprises, creation of strong regional governance structures, effective coordination of public sector agencies at regional level, and radical reorganisation of the local government system - remain as relevant today as they did then. The fact that no meaningful progress has been made in achieving these objectives - a situation which is unlikely to change significantly under the NPF - is a sad reflection of the inability to learn and resistance to change in this sphere within the Irish state apparatus.

\section{References}

Bartley, B. (2001). The emergence and evolution of urban planning in Ireland. Geographical Viewpoint, 29, 7-14.

Boudeville, J. R. (1966). Problems of regional economic planning. Edinburgh: Edinburgh University Press.

Breathnach, P. (1982). The demise of growth centre policy: The case of the Republic of Ireland. In R. Hudson \& J. Lewis (Eds), Regional planning in Europe (pp. 35-56). London: Pion Ltd.

Breathnach, P. (1991, May 15). The role of advance factories in regional industrial planning in the Republic of Ireland. Paper presented at Conference of Irish Geographers, University College Cork.

Breathnach, P. (1993). Women's employment and peripheralisation: The case of Ireland's branch plant economy. Geoforum, 24 (1), 19-29.

Breathnach, P. (1998). Exploring the 'Celtic tiger' phenomenon: Causes and consequences of Ireland's economic miracle. European Urban and Regional Studies, 5 (4), 305-16.

Breathnach, P. (2010). From spatial Keynesianism to post-Fordist neoliberalism: Emerging contradictions in the spatiality of the Irish state. Antipode, 42 (5), 1180-99.

Breathnach, P. (2014). Creating city-region governance structures in a dysfunctional polity: The case of Ireland's National Spatial Strategy. Urban Studies, 51 (11), 2267-84.

Breathnach, P. (2017, October 15). The National Planning Framework: Key governance issues. Paper presented at Political Studies Association of Ireland Annual Conference, Dublin. 
Brenner, N. (2004). Urban governance and the production of new state spaces in Western Europe, 1960-2000. Review of International Political Economy, 11, 447-88.

Buchanan, C. (1964). Traffic in towns. London: Penguin.

Buchanan, M. (2001, December 10). Professor Sir Colin Buchanan. Retrieved from https://www.independent.co.uk/news/obituaries/professor-sir-colinbuchanan-9241466.html [24 February 2019].

Colin Buchanan and Partners. (1968). Regional studies in Ireland. Dublin: An Foras Forbartha.

Committee on Development Centres and Industrial Estates. (1965). Report. Dublin: The Stationery Office.

Committee on Industrial Organisation. (1963). Fourth interim report: Industrial grants. Dublin: The Stationery Office.

Darwent, D. F. (1969). Growth poles and growth centres in regional planning - A review. Environment and Planning A, 1 (1), 5-32.

Department of the Environment, Community and Local Government. (2012). Putting people first: Action programme for effective local government. Dublin: The Stationery Office.

Expert Group. (2014). Review of the National Spatial Strategy: Views of Expert Group. Retrieved from http://npf.ie/wp-content/uploads/2017/02/ EXPERT-GROUP-SCOPING-REPORT-JAN-2014.pdf [16 June 2019].

Forfás. (2006). Implementing the NSS: Gateway investment priorities study. Dublin: Forfás.

Gillmor, D. A. (1985). Economic activity in the Republic of Ireland. Dublin: Gill and Macmillan.

Hansen, N. M. (1967). Development pole theory in a regional economic context. Kylos, 20, 709-27.

Industrial Development Authority. (1972). Regional industrial plans 19731977: Part 1. Dublin: Industrial Development Authority.

Keating, M. (1998). The new regionalism in Western Europe. Cheltenham: Edward Elgar.

Loughlin, J. (2001). Conclusions: The transformation of regional and local democracy in Western Europe. In J. Loughlin (Ed.), Subnational democracy in the European Union (pp. 387-400). Oxford: Oxford University Press.

Luttrell, W. (1962). Factory location and industrial movement. London: National Institute of Economic and Social Research.

National Competitiveness Council. (2009). Our cities: Drivers of national competitiveness. Dublin: Forfás.

National Economic and Social Council. (1975). Regional policy in Ireland: A review. Dublin: The Stationery Office.

National Economic and Social Council. (2008). The Irish economy in the early 21st century. Dublin: National Economic and Social Council.

National Industrial and Economic Council. (1965). Comments on Report of the Committee on Development Centres and Industrial Estates. Dublin: The Stationery Office. 
Parkinson, M., Harding, A., \& Dawson, J. (1994). Introduction: The changing face of urban Europe. In A. Harding, J. Dawson, R. Evans \& M. Parkinson (Eds.), European cities towards 2000 (pp. 1-16). Manchester: Manchester University Press.

Pike, A., Rodríguez-Pose, A., \& Tomaney, J. (2006). Local and regional development. Abingdon: Routledge. 